\title{
The Emerging Genetic Basis and Its Clinical Implication in Pancreatic Cancer
}

\author{
Fei Chen ${ }^{a}$ Yang Guo ${ }^{a}$ Liangjing Wang ${ }^{a, b}$ \\ a Department of Gastroenterology, School of Medicine, The Second Affiliated \\ Hospital, Zhejiang University, and ${ }^{\mathrm{b}}$ Institute of Gastroenterology, Zhejiang University, \\ Hangzhou, China
}

\section{Key Words}

Clinical application · Genetic alteration · Pancreatic cancer

\begin{abstract}
Background: Pancreatic cancer is one of the most devastating diseases without early detection, effective screening biomarkers and therapeutic treatments. In the past decades, genetic studies have indicated various genes related to this malignancy. Summary: Genetic alterations have been involved in the initiation, progression and invasion of pancreatic cancer, which might indicate promising targets for early screening, diagnosis and future intervention. Here we will review genetic changes in pancreatic cancer and analyze their correlations with several common precursors and familial syndromes. Key Message: Genetic analysis for pancreatic cancer or its precursors might help us to characterize patients into subtype individuals in the future and have significant implications for individualized treatments. Practical Implications: At present, pancreatic cancer is regarded as a disease with a wide range of genetic alterations, including germline and somatic mutations. Some genetic alterations such as KRAS, p16 CDKN2A, TP53 and SMAD4 were specifically correlated with different types of histological precursors of pancreatic cancer and some familial syndromes highly related to pancreatic cancer. Moreover, genetic changes also predict drug sensitivity and implicate novel therapeutic targets.
\end{abstract}

(C) 2015 S. Karger AG, Basel

\section{Introduction}

Pancreatic cancer is the fourth leading cause of cancer mortality among males and females in the United States and seventh in China [1,2]. Despite enormous breakthroughs in cancer therapy in the past decades, the mortality rate for pancreatic cancer is still increasing [1]. Surgery is believed to be the only curative tool for pancreatic cancer patients [3]. However, 
the 5-year survival rate for patients with localized disease after surgical resection is $24 \%$ and only $2 \%$ for those with metastatic disease [1]. Moreover, due to lack of specific symptoms at an early stage and the absence of effective diagnostic biomarkers, up to $80 \%$ of patients are diagnosed at an advanced stage and not eligible for surgery [4]. For most patients, adjuvant and neoadjuvant chemotherapy based on gemcitabine might be the most effective treatment [5]. However, the median survival for locally advanced or metastatic pancreatic cancer patients treated with gemcitabine is only 7.9 months [6].

Although the overall survival rate for pancreatic cancer patients has remained dismal in the past years, various approaches have been investigated to improve this result. Prevention and early detection appear to be the first effective ways. Prevention includes controlling risk factors such as cigarette smoking, blood glucose level, obesity, etc. [7, 8]. Recent surveillance methods include the detection of serum CEA and CA19-9 level [9]. Imaging has been greatly improved with the development of computed tomography scans, magnetic resonance imaging and endoscopic ultrasonography (EUS) [10, 11]. However, none of these methods can be used alone for diagnosis and the optimal strategy has not yet been determined. Although EUS is effective in detecting small lesions, abnormalities on EUS are not specific for early detection of pancreatic cancer because of lacking specific biomarkers [12].

In the past years, researchers have studied the molecular basis of cancer initiation, progression and metastasis in various tumor entities. Substantial progress has been made in understanding the genomic initiation of pancreatic cancer. Moreover, it has been recognized that pancreatic cancer has close associations with three types of histological precursors, namely pancreatic intraepithelial neoplasia (PanIN), intraductal papillary mucinous neoplasm (IPMN) and mucinous cystic neoplasm (MCN). Interestingly, all of these precursor lesions are related to specific genetic alterations [13]. In particular, several key gene mutations were found in a majority of familial pancreatic cancer (FPC) cases. Additionally, novel genetic studies indicated that mutated KRAS and p53 are involved in inherited or acquired drug resistance, including gemcitabine treatment [14-17].

In this review, we will summarize the related genetic changes in pancreatic cancer and their correlations with several important precursors of pancreatic cancer and specific familial syndromes, which might provide help for early screening, pathological classification, diagnostic, predictive and prognostic implications.

\section{Genetics of Pancreatic Cancer}

Pancreatic ductal adenocarcinoma (PDAC) accounts for $>90 \%$ of all pancreatic neoplasms [1]. These tumors are derived from pancreatic ductal cells. Until now, PDAC has been regarded as a disease with a wide range of genetic alterations, including germline and somatic mutations. In the majority of invasive PDAC, the genetic abnormalities with high frequency are mutational activation of the KRAS oncogene, inactivation of tumor suppressor genes including p16 ${ }^{C D K N 2 A}, T P 53, S M A D 4 / D P C 4$ and BRCA2, widespread chromosomal losses, gene amplifications and telomere shortening [18]. In a few $(<20 \%)$ pancreatic cancers, genes mutated with low frequency include oncogenes such as $B R A F, M Y B, A K T 2$ and $E G F R$, and tumor suppressor genes such as MKK4, MAP2K4, STK11, TGFBR1, TGFBR2, ACVR1B, ACVR2A, FBXW7 and EP300 $[19,20]$.

\section{Oncogenes}

KRAS. The KRAS gene is located on chromosome arm $12 \mathrm{p}$ and encodes a membranebound guanosine triphosphate-binding protein. It mediates various cellular functions, in- 
cluding proliferation, cellular survival, motility and cytoskeletal remodeling [21]. Activation of KRAS mutations appears to be the initial genetic change that is detected in the progression series, occurring occasionally in histologically normal pancreas and in about $30 \%$ of lesions that show the earliest stages of histological disturbance. This has been found in $>95 \%$ of pancreatic cancers and the gene is mainly activated by point mutations, a single amino acid substitution from $\mathrm{G}$ to $\mathrm{D}$ at codon 12 [19, 22]. In pancreatic cancer, KRAS has been involved in three major pathways, including RAF/MEK/ERK, PI3K/Pdk1/AKT and the Ral guanine nucleotide exchange factor pathway [23-25]. Loss of KRAS expression results in massive cell death and arrested proliferation, leading to rapid tumor regression [26]. Recently, tumors with KRAS mutations have been characterized by constitutively high levels of autophagy [27]. $K R A S$ participated in this process by altering the expression of enzymes involved in glucose utilization [26].

GNAS. GNAS mutations are reported as a frequently observed early genetic aberration in IPMNs. Studies found that nearly $50 \%$ of IPMNs harbored GNAS mutations, and $51 \%$ harbored both GNAS and KRAS mutations [28]. GNAS is located on chromosome 20q13.32 and encoded G-protein alpha subunit [29]. GNAS mutations were observed both in low- and high-grade tumors as well as in invasive tumors [28]. They might play an important role in the initiation of IPMN.

\section{Tumor Suppressor Genes}

$p 16^{C D K N 2 A}$. The $\mathrm{p} 16^{\mathrm{CDNN2A}}$ protein is a cyclin-dependent kinase inhibitor. It is related to several different mechanisms such as homozygous deletion or promoter hypermethylation [30]. The $p 16^{C D K N 2 A}$ gene has been found to be inactivated in 95\% of PDACs. It locates at 9q21 and encodes two tumor suppressors, INK4A and $A R F$ [31]. In most pancreatic cancers, homozygous deletion of $9 \mathrm{p} 21$ causes the loss of both transcripts, thereby disrupting the related RB and p53 tumor suppression pathways. INK4A inhibits CDK4/CDK6-mediated phosphorylation of $\mathrm{RB}$, thereby blocking entry into the $\mathrm{S}$ phase of the cell cycle. $A R F$ stabilizes 53 by inhibiting its MDM2-dependent proteolysis. Compared to $A R F$, INK4A seems to be a dominant suppressor gene at this locus, as it is more frequent in germline and sporadic mutations [32].

TP53. The mutation of tumor protein 53 (TP53) is observed in up to $75 \%$ of pancreatic cancers [33]. It is regarded as a late event during PanIN progressing to PDAC and seems to be more frequent in IPMNs [34]. TP53 encodes the p53 protein. p53 plays an important role in cellular stress responses, particularly by activating DNA repair, inducing growth arrest and triggering apoptosis. It mediates G1 block [35] and has a close relationship with G2/M block [36] by upregulating p53 up-regulated modulator of apoptosis (PUMA) and binding to BCL2 [37]. Loss of p53 function through mutation of the TP53 gene therefore promotes pancreatic neoplasm through the loss of critical cell functions [38]. In mice containing oncogenic KRAS and lacking $\mathrm{p} 53$, loss of autophagy no longer blocks tumor progression, but actually accelerates carcinogenesis [39]. Unlike most tumor suppressor genes, inactivation of the TP53 gene typically occurs through missense mutations of one allele, accompanied by loss of the other allele. The majority of these missense mutations are clustered in hot spot residues, mainly within the DNA binding domains [40].

$S M A D 4 / D P C 4$. Another frequent genetic alteration in PDAC is the loss of SMAD4/DPC4. This gene maps to chromosome 18q21, a region that sustains deletion in approximately $55 \%$ of pancreatic cancers, mainly by homozygous deletion [41]. SMAD4 encodes a transcriptional regulator that is a keystone component in the transforming growth factor- $\beta$ (TGF- $\beta$ ) family signaling cascade. Loss of SMAD4 function abolishes the SMAD4-dependent TGF- $\beta$ pathway and gives rise to unregulated cellular proliferation [42]. Patients with tumors that harbor a wild-type SMAD4 gene have a lower propensity for widespread metastasis than those with 
loss of SMAD4, and loss of DPC4 expression was closely related to a low survival rate [43]. Loss of nuclear SMAD4 frequently occurs in pancreatic adenocarcinomas, but not in extrapancreatic malignancies [44].

$B R C A 2$. Inherited BRCA2 mutations are typically associated with hereditary breastovarian cancer (HBOC) syndrome, but also carry a significant risk for the development of pancreatic cancer. BRCA2, located on $13 q 12.3$, approximately accounts for $24 \%$ of sporadic pancreatic cancers [20]. In normal cells, BRCA2 maintains genomic stability through regulating the homologous recombination-based DNA repair process. Tumor cells with defective $B R C A 2$ lack the ability to repair DNA, rendering the cells more susceptible to cell death [45]. Thus, BRCA2 deficiency results in the accumulation of lethal chromosomal aberrations [46]. Loss of wild-type BRCA2 seems to be a late event in those individuals who inherit germline heterozygous mutations of $B R C A 2$, which predisposes to severely dysplastic PanINs and adenocarcinomas [47].

\section{Other Less Frequent Mutations}

There are many less frequently mutated genes in pancreatic cancer. AKT2 gene mutation was found in $20 \%$ of pancreatic cancers [48]. Amplifications of some oncogenes such as $C$-MYC, KRAS and GATA6 were less frequent $[19,49]$. Homozygous deletions of the suppressor gene $M K K 4$ were found in about $2 \%$ of pancreatic cancer cases. Interestingly, MKK4 functions as a downstream effector of DPC4, $16^{C D K N 2 A}, T P 53$ and BRCA2 [50]. Recent reports indicated that genes mutated in a few $(<20 \%)$ pancreatic cancers, including oncogenes such as $B R A F, M Y B, A K T 2$ and EGFR, and tumor suppressor genes such as MAP2K4, STK11, TGFBR1, TGFBR2, ACVR1B, ACVR2A and FBXW7 [19]. Moreover, structural analysis of mutated genes indicated PIK3CG, DGKA, STK33, TTK and PRKCG as low-frequency driver mutations [51].

\section{Clinical Implications of Genetic Alterations in Pancreatic Cancer}

\section{Screening of Hereditary and FPC Syndromes}

Approximately $10 \%$ of pancreatic cancers have a familial basis [52, 53]. Familial aggregations are related to several syndromes, such as Peutz-Jeghers syndrome (PJS), familial atypical multiple mole melanoma (FAMMM) syndrome, HBOC syndrome, hereditary nonpolyposis colorectal carcinoma (HNPCC) syndrome, familial adenomatous polyposis (FAP) syndrome, Li-Fraumeni syndrome, ataxia telangiectasia, hereditary pancreatitis, cystic fibrosis and FPC syndrome [54,55]. Of note, various germline gene alterations have been found to be involved in these syndromes.

\section{PJS}

PJS is an autosomal dominant hamartomatous polyposis syndrome. Patients with PJS have an increased incidence of pancreatic cancer [56]. Interestingly, $>80 \%$ of PJS cases are caused by inherited mutations in the tumor suppressor gene STK11/LKB1 (chromosome 19p13) [57]. PJS patients have a high predisposition to other gastrointestinal cancers, including colorectal cancer (39\%), gastric cancer (29\%) and small bowel adenocarcinomas $(13 \%)[58,59]$. Females with PJS are even at high risk for breast cancer $(54 \%)$ and gynecologic malignancies, including ovarian tumors (21\%), endometrial cancer (9\%) and adenoma malignum of the cervix (10\%) [58]. Individuals with PJS harbor a 132-fold increased risk of pancreatic cancer (table 1). Moreover, patients with PJS are at increased risk for IPMNs and their precursors [60]. All this is a profound implication for the screening and management of pancreatic cysts in patients with PJS [61]. 
Table 1. Inherited predisposition to pancreatic cancer

\begin{tabular}{llll}
\hline Syndrome & Genetic defect & $\begin{array}{l}\text { Histological feature of } \\
\text { pancreatic neoplasm }\end{array}$ & $\begin{array}{l}\text { Predisposition } \\
\text { to pancreatic } \\
\text { cancer (folds) }\end{array}$ \\
\hline PJS & STK11/LKB1 & ductal adenocarcinoma, IPMN & 132 \\
FAMMM syndrome & $p 16^{C D K N 2 A}$ & ductal adenocarcinoma & $13-38$ \\
HBOC syndrome & BRCA1, BRCA2, FANCN, PALB2 & ductal adenocarcinoma & $3.5-10$ \\
HNPCC syndrome & $M S H 2$, MLH1, PMS1, PMS2, MSH6/GTBP & medullary carcinoma & 8.6 \\
FAP syndrome & dPC & ductal adenocarcinoma & 4 \\
Li-Fraumeni syndrome & TP53 & unknown & elevated \\
Ataxia telangiectasia & uTM & unknown & elevated \\
Hereditary pancreatitis & $P R S S 1$, SPINK1 & unknown & 58 \\
Cystic fibrosis & $C F T R$ & ductal adenocarcinoma & elevated \\
FPC syndrome & unknown & & $2-32$
\end{tabular}

\section{FAMMM Syndrome}

FAMMM syndrome is an autosomal dominantly inherited syndrome with incomplete penetrance. The germline mutation $p 16^{C D K N 2 A}$ gene is strongly associated with FAMMM syndrome, although the prevalence was inconsistent [62-64]. Except for pancreatic cancer, individuals with FAMMM syndrome are also at increased risk of developing sarcomas, lung and breast cancers $[65,66]$. The risk of pancreatic cancer in kindreds with FAMMM syndrome is 13- to 22 -fold higher than in the average population [65, 67], and individuals with a germline $p 16^{C D K N 2 A}$ mutation have a 38-fold higher risk of pancreatic cancer than the general population (table 1) [68].

\section{HBOC Syndrome}

HBOC syndrome is an autosomal, dominantly inherited syndrome associated with germline mutations in BRCA1, BRCA2 and other genes in the Fanconi anemia pathway (FANCN/PALB2) $[11,69]$. Among them, germline mutations of BRCA2 have the highest prevalence $(5-17 \%)$ in inherited PDAC $[11,70,71]$. In patients with pancreatic cancer and two or more first-degree relatives with pancreatic cancer, the prevalence of BRCA2 mutations has been estimated to range from 17 to $19 \%$ [69, 71]. In a study of 173 families with germline BRCA2 mutations and breast/ ovarian cancers, representing a cohort of 3,728 individuals, the relative risk of pancreatic cancer was 3.51 (table 1) [72]. The incidence of pancreatic cancer is especially high in families of Ashkenazi Jewish descent, where a germline BRCA2 $2^{6174 d e l T}$ mutation has been reported [73].

\section{HNPCC Syndrome}

HNPCC syndrome, also named Lynch syndrome, is a dominant autosomal disease [74]. It is associated with germline mutations of mismatch repair genes, including $M L H 1, M S H 2$, PMS1, PMS2 and MSH6/GTBP [75]. Except for pancreatic cancer, patients with HNPCC syndrome also have an increased risk of other cancers such as endometrial, gastric, small intestinal and ureteral cancers [74]. A recent study showed that 147 families containing mismatch repair gene mutation in a mismatch gene had an 8.6-fold (95\% CI 4.7-15.7) increased risk of pancreatic cancer as compared to the general population (table 1) [76]. This corresponds to a 3.68\% (95\% CI 1.45-5.88\%) lifetime risk of pancreatic cancer (by age 70) [76]. When patients with HNPCC syndrome develop pancreatic cancer, they usually have a characteristic medullary phenotype. Some often harbor microsatellite instability and a distinctly poor differentiated medullary histopathology [77]. 


\section{FAP Syndrome}

FAP syndrome is an autosomal, dominantly inherited disease [78, 79]. Germline mutation of $A P C$ is linked with FAP syndrome. It is estimated that this alteration increases 4-fold the risk for pancreatic cancer, while it also has an elevated incidence of early colonic polyps and adenocarcinoma (table 1) [80]. APC mutation causes derangement of Wnt signaling, which leads to pancreatic ampullary cancer or duodenal cancer.

\section{Hereditary Pancreatitis}

Hereditary pancreatitis is a rare inherited form of pancreatitis [81]. Mutations in the cationic trypsinogen gene (PRSS1) on chromosome 7q35 cause an autosomal dominant form of hereditary pancreatitis, whereas mutations in the serine protease inhibitor gene (SPINK1) on chromosome 5q32 cause an autosomal recessive form of hereditary pancreatitis [82-84]. Patients with hereditary pancreatitis have a remarkable 58-fold (95\% CI 23-105) increased risk of pancreatic cancer and a lifetime risk of pancreatic cancer of $30-40 \%$ (by age 70 ) (table 1) $[85,86]$.

\section{Pancreatic Cancer Families Screening}

Individuals with at least a 5- to 10 -fold increased risk of pancreatic cancer, such as members of FPC families with at least two affected first-degree relatives, might be candidates for long-term surveillance and screening $[11,87]$. Genetic alterations might be effective for screening [11]. Pancreatic surgery can be performed when a suspicious lesion is identified.

\section{Pathological Classification}

With the increasing sensitivity of novel imaging modalities, occasional pancreatic cysts become more discernible. Most of these do not require surgical intervention because of the low risk of malignancy. However, some might be high-risk lesions, such as IPMN and MCN. Studies on IPMN indicate that approximately $70 \%$ of main pancreatic duct IPMNs may progress into invasive cancer [88]. Thus, it is important to identify some biomarkers to differentiate low- from high-risk lesions, consequently appropriately stratifying patients for either surveillance or surgical intervention.

KRAS might be an essential biomarker (table 2). During the progression from PanIN-1 to PanIN-2 and PanIN-3 lesions, KRAS mutation is an important early event and the rate in PanIN patients becomes higher [22, 89]. It is reported that approximately $45 \%$ of PanIN-1 lesions carried a KRAS mutation [89]. Moreover, through loss of heterozygosity analyses, $p 16^{C D K N 2 A}$, TP53 and SMAD4 have also been related to the progression of PanIN [90]. Inactivating mutations of $p 16^{C D K N 2 A}$ through promoter hypermethylation are found in PanIN-2 lesions [91]. It has been demonstrated that functional abrogation of $p 16^{C D K N 2 A}$ is one of the early events in pancreatic ductal carcinogenesis [92]. Inactivation of TP53 and SMAD4 are generally associated with PanIN-3 [91]. These findings might provide a genetic basis for the progression of PanINs to PDAC and the staging of PanINs.

\section{Diagnostic Biomarkers}

The analysis of gene mutation might also shed light on the differential diagnosis for pancreatic premalignant mucinous lesions. Activating point mutations of KRAS occur in approximately $50 \%$ of IPMNs with low-grade dysplasia, and the prevalence of KRAS mutations increases the grading of dysplasia [93]. It has been reported that EUS fine needle aspiration plus KRAS mutation analysis might significantly improve accuracy in the diagnosis of pancreatic cancer [94].

Moreover, inactivated mutations of $p 16^{C D K N 2 A}$ and TP53 are found in IPMNs with highgrade dysplasia [95] (table 2). GNAS mutations are reported as a frequently observed early 
Chen et al.: The Emerging Genetic Basis and Its Clinical Implication in Pancreatic Cancer

Table 2. Genetic alterations in common neoplasms of the pancreas

\begin{tabular}{|c|c|c|c|}
\hline Tumor type & Related gene & $\begin{array}{l}\text { Prevalence of genetic } \\
\text { alteration }\end{array}$ & Implications \\
\hline PDAC & $\begin{array}{l}\text { KRAS } \\
p 16^{C D K N 2 A} \\
\text { TP53 } \\
\\
\text { SMAD4 } \\
\text { EP300 } \\
\text { BRCA2 } \\
\text { ARID1A/B } \\
\text { MKK4 }\end{array}$ & $\begin{array}{l}55 \% \\
25 \% \\
24 \% \\
10 \% \\
2 \%\end{array}$ & $\begin{array}{l}\text { target for early detection } \\
\text { related to } \mathrm{G} 1 \text { arrest } \\
\text { associated with tumor differentiation and } \\
\text { locoregional recurrence } \\
\text { predictor for poor prognosis } \\
\text { predictor for poor prognosis } \\
\text { regulating DNA damage } \\
\text { regulating SWI/SNF-mediated chromatin remodeling } \\
\text { downstream regulator of } D P C 4, p 16^{C D K N 2 A}, T P 53 \text { and } \\
B R C A 2\end{array}$ \\
\hline PanIN & $\begin{array}{l}\text { KRAS } \\
p 16^{C D K N 2 A} \\
\text { TP53 } \\
\text { SMAD4 }\end{array}$ & $\begin{array}{l}\text { varied upon grading } \\
\text { varied upon grading } \\
\text { varied upon grading } \\
\text { varied upon grading }\end{array}$ & $\begin{array}{l}\text { at the early stage of PanIN } \\
\text { related to differentiation } \\
\text { related to Pan-3 } \\
\text { related to Pan-3 }\end{array}$ \\
\hline IPMN & $\begin{array}{l}\text { KRAS } \\
\text { GNAS } \\
\text { RNF43 } \\
\text { p16 } \\
\text { TPKN2A } \\
\text { EGFR }\end{array}$ & $\begin{array}{l}81 \% \\
60 \% \\
50 \% \\
\text { varied upon grading } \\
\text { varied upon grading } \\
7.5 \%\end{array}$ & $\begin{array}{l}\text { related to grade rise } \\
\text { marker of IPMN } \\
\text { regulating Wnt signaling pathway } \\
\text { related to high-grade dysplasia } \\
\text { related to high-grade dysplasia } \\
\text { related to intestine-type IPMNs }\end{array}$ \\
\hline MCN & $\begin{array}{l}\text { KRAS } \\
\text { SMAD4 } \\
\text { TP53 }\end{array}$ & $\begin{array}{l}75 \% \\
\text { varied upon grading } \\
\text { varied upon grading }\end{array}$ & $\begin{array}{l}\text { accumulating with differentiation } \\
\text { at the late stage of neoplastic progression from MCNs } \\
\text { related to staging }\end{array}$ \\
\hline $\begin{array}{l}\text { Acinar cell } \\
\text { carcinoma }\end{array}$ & $\begin{array}{l}A P C \\
\text { CTNNB1 }\end{array}$ & $\begin{array}{l}\text { inconsistent } \\
\text { inconsistent }\end{array}$ & $\begin{array}{l}\text { involved in Wnt signaling pathway } \\
\text { involved in Wnt signaling pathway }\end{array}$ \\
\hline PanNET & $\begin{array}{l}\text { DAXX or ATRX } \\
\text { PIK3CA, PTEN, TSC2 }\end{array}$ & $\begin{array}{l}45 \% \\
15 \%\end{array}$ & $\begin{array}{l}\text { marker of PanNETs } \\
\text { therapeutic target }\end{array}$ \\
\hline $\begin{array}{l}\text { Pancreato- } \\
\text { blastoma }\end{array}$ & $\begin{array}{l}\text { loss of chromosome } 11 \mathrm{p} \\
\text { CTNNB1 } \\
\text { APC }\end{array}$ & $\begin{array}{l}85 \% \\
55 \% \\
10 \%\end{array}$ & $\begin{array}{l}\text { genetic abnormality in pancreatoblastoma } \\
\text { related to the APC } / \beta \text {-catenin pathway } \\
\text { related to the APC } / \beta \text {-catenin pathway }\end{array}$ \\
\hline
\end{tabular}

PanNET(s) = Pancreatic neuroendocrine tumor(s).

genetic aberration in IPMNs. Studies of MCNs have indicated the prevalence of KRAS mutations and aberrant nuclear p53 accumulation with increasing grades of dysplasia [96]. Although SMAD4 mutation and loss of nuclear expression are not observed in most noninvasive MCNs, its loss of expression was often found in the progression from MCNs to infiltrating cancers. Inactivation of SMAD4 is regarded as the late event of neoplastic progression from MCNs [97]. Furthermore, tumor microsatellite instability testing in patients with a family history appears to be an effective way for the surveillance of Lynch syndrome or the presence of young-onset medullary cancer of the pancreas.

\section{Predictive Biomarkers}

During the past decade, numerous chemotherapeutic and molecular targeted agents have been evaluated alone or in combination in various clinical trials. Chemotherapeutic agents including DNA-damaging agents, such as fluorouracil, oxaliplatin and gemcitabine, are 
Chen et al.: The Emerging Genetic Basis and Its Clinical Implication in Pancreatic Cancer

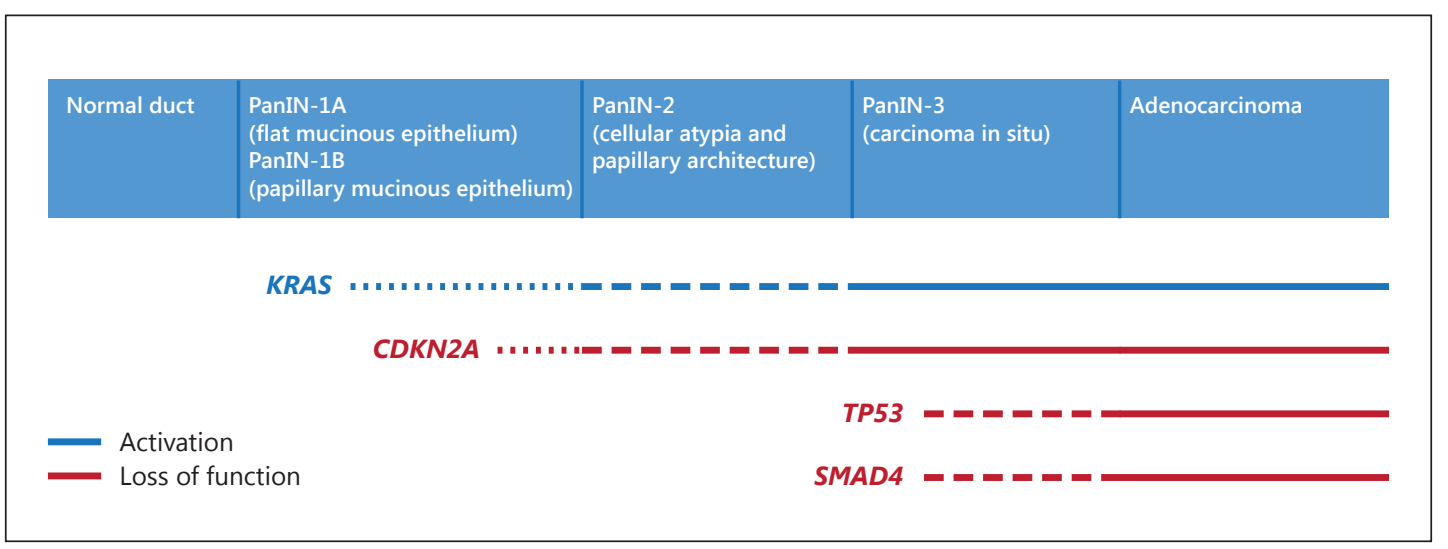

Fig. 1. Possible initiating events of genetic alterations in PDAC. Activation of $K R A S$ might be the first event in PanIN. With progression, CDKN2A, TP53 and SMAD4 might be activated. Among these three, loss of the expression of CDKN2A might be the major event for PanIN-1 and PanIN-2, whereas inactivation of TP53 and SMAD4 might be generally associated with PanIN-3.

widely used in pancreatic cancer. Recently, many novel therapies were tested, including molecular targeted therapies. Among them, only erlotinib, which targets the epidermal growth factor receptor, has been shown to improve survival in combination with gemcitabine as compared to gemcitabine alone [98]. Still, innate and acquired drug resistance remains unknown [14]. KRAS and BCL2 have been involved in drug resistance in pancreatic cancer [99]. Mutation of KRAS results in constitutive activation of the RAS/RAF/MEK/ERK pathway, with loss of epidermal growth factor receptor signaling control, rendering inhibitors of $E G F R$ ineffective [15]. KRAS also induces PEAK1 amplification and desensitizing cancer cells to trastuzumab and gemcitabine [17]. Gemcitabine stabilized mutant p53 protein in the nuclei and induced chemoresistance [16]. KRAS knockdown abolished the insulin-like growth factor-1-induced ERK pathway in KRAS-mutated cancer cells and enhanced the therapeutic efficacy of everolimus [100]. The overexpression of $c$-Met, a mesenchymal-epithelial transition factor gene, promotes anti-apoptotic effects via PI3K-AKT activation, consequently reducing the sensitivity towards gemcitabine $[101,102]$. SIRT1 was overexpressed in pancreatic cancer and downregulation of SIRT1 could enhance chemosensitivity [103].

\section{Prognostic Biomarkers}

It has been reported that p53 is strongly associated with tumor differentiation and presence of locoregional recurrence [104]. Loss of $p 16^{C D K N 2 A}$ was associated with lymphatic invasion and postoperative widespread metastasis [104]. A significant correlation was found among SMAD4/DPC4 and tumor size, lymphatic invasion and lymph node metastasis. Loss of $S M A D 4 / D P C 4$ was significantly associated with shorter overall survival. Multivariate analysis revealed that loss of SMAD4/DPC4 was an independent and significant poor prognostic factor for overall and disease-free survival [104].

\section{Therapeutic Targets}

With better understanding of chemoresistance in pancreatic cancer, new approaches have emerged. For example, to overcome the resistance mechanism related to the RAS/RAF/ MEK/ERK pathway, several novel inhibitors including MEK inhibitors, BRAF inhibitors, HSP90 inhibitors, KRAS-directed immunotherapy, mTOR inhibitors and several combinations thereof have been tested [15]. An interplay between the $\mathrm{N}$-terminus domain of secreted 
protein and rich in cysteine (SPARC), BCL2 and CASPASE-8 helps to augment apoptosis and consequently increase the response to treatment [105]. Combination treatment of gemcitabine and p53-reactivating molecules (CP-31398 and RITA) inhibits the proliferation of pancreatic cancer cells and induced apoptosis [16]. The inhibition of poly(adenosine diphosphateribose) polymerase (PARP) might be a potential synthetic lethal therapeutic strategy for the treatment of cancers with specific DNA repair defects, including carriers with BRCA1 or BRCA2 mutation [106].

\section{Conclusion}

Although pancreatic cancer remains as a dismal disease, genetic studies indicate that genetic alterations might be useful for diagnosis, treatment and prognosis (table 2). Mutations including KRAS, p16 ${ }^{C D K N 2 A}$, p53 and SMAD4 might provide a molecular basis for the progression from PanINs to pancreatic cancer (fig. 1). With more genes being identified, diagnosis and staging of pancreatic cancer and precursor lesions according to gene mutations might be more discernible and advisable for further treatment. Moreover, it might help to characterize and stratify cancer patients into subgroups for individualized treatments.

\section{Acknowledgments}

This work was supported by the Natural Science Foundation of China $(81472214,81272678)$ and by the Science and Technology Innovation Team of Zhejiang Province in China (2013TD13).

\section{Disclosure Statement}

The authors declare that there are no conflicts of interest.

\section{References}

1 Siegel RL, Miller KD, Jemal A: Cancer statistics, 2015. CA Cancer J Clin 2015;65:5-29.

2 Chen W, Zheng R, Zeng H, Zhang S, He J: Annual report on status of cancer in China, 2011. Chin J Cancer Res 2015;27:2-12.

-3 Ryan DP, Hong TS, Bardeesy N: Pancreatic adenocarcinoma. N Engl J Med 2014;371:1039-1049.

$\checkmark 4$ Wolfgang CL, Herman JM, Laheru DA, Klein AP, Erdek MA, Fishman EK, Hruban RH: Recent progress in pancreatic cancer. CA Cancer J Clin 2013;63:318-348.

5 Herreros-Villanueva M, Hijona E, Cosme A, Bujanda L: Adjuvant and neoadjuvant treatment in pancreatic cancer. World J Gastroenterol 2012;18:1565-1572.

-6 Mukherjee S, Hurt CN, Bridgewater J, Falk S, Cummins S, Wasan H, Crosby T, Jephcott C, Roy R, Radhakrishna G, McDonald A, Ray R, Joseph G, Staffurth J, Abrams RA, Griffiths G, Maughan T: Gemcitabine-based or capecitabine-based chemoradiotherapy for locally advanced pancreatic cancer (SCALOP): a multicentre, randomised, phase 2 trial. Lancet Oncol 2013;14:317-326.

7 Hermann PC, Sancho P, Canamero M, Martinelli P, Madriles F, Michl P, Gress T, de Pascual R, Gandia L, Guerra C, Barbacid M, Wagner M, Vieira CR, Aicher A, Real FX, Sainz B Jr, Heeschen C: Nicotine promotes initiation and progression of KRAS-induced pancreatic cancer via Gata6-dependent dedifferentiation of acinar cells in mice. Gastroenterology 2014;147:1119-1133.e4.

8 Liao WC, Tu YK, Wu MS, Lin JT, Wang HP, Chien KL: Blood glucose concentration and risk of pancreatic cancer: systematic review and dose-response meta-analysis. BMJ 2015;349:g7371.

-9 Reitz D, Gerger A, Seidel J, Kornprat P, Samonigg H, Stotz M, Szkandera J, Pichler M: Combination of tumour markers CEA and CA19-9 improves the prognostic prediction in patients with pancreatic cancer. J Clin Pathol 2015;68:427-433.

10 Cote GA, Smith J, Sherman S, Kelly K: Technologies for imaging the normal and diseased pancreas. Gastroenterology 2013;144:1262-1271.e1. 
11 Canto MI, Harinck F, Hruban RH, Offerhaus GJ, Poley JW, Kamel I, Nio Y, Schulick RS, Bassi C, Kluijt I, Levy MJ, Chak A, Fockens P, Goggins M, Bruno M; International Cancer of Pancreas Screening (CAPS) Consortium: International Cancer of the Pancreas Screening (CAPS) Consortium summit on the management of patients with increased risk for familial pancreatic cancer. Gut 2013;62:339-347.

-12 Chari ST, Kelly K, Hollingsworth MA, Thayer SP, Ahlquist DA, Andersen DK, Batra SK, Brentnall TA, Canto M, Cleeter D, Firpo MA, Gambhir SS, Go VL, Hines OJ, Kenner BJ, Klimstra DS, Lerch MM, Levy MJ, Maitra A, Mulvihill SJ, Petersen GM, Rhim AD, Simeone DM, Srivastava S, Tanaka M, Vinik AI, Wong D: Early detection of sporadic pancreatic cancer: summative review. Pancreas 2015;44:693-712.

13 Delpu Y, Hanoun N, Lulka H, Sicard F, Selves J, Buscail L, Torrisani J, Cordelier P: Genetic and epigenetic alterations in pancreatic carcinogenesis. Curr Genomics 2011;12:15-24.

14 Long J, Zhang Y, Yu X, Yang J, LeBrun DG, Chen C, Yao Q, Li M: Overcoming drug resistance in pancreatic cancer. Expert Opin Ther Targets 2011;15:817-828.

15 Lopez-Chavez A, Carter CA, Giaccone G: The role of KRAS mutations in resistance to EGFR inhibition in the treatment of cancer. Curr Opin Investig Drugs 2009;10:1305-1314.

-16 Fiorini C, Cordani M, Padroni C, Blandino G, Di Agostino S, Donadelli M: Mutant p53 stimulates chemoresistance of pancreatic adenocarcinoma cells to gemcitabine. Biochim Biophys Acta 2015;1853:89-100.

$\checkmark 17$ Kelber JA, Reno T, Kaushal S, Metildi C, Wright T, Stoletov K, Weems JM, Park FD, Mose E, Wang Y, Hoffman RM, Lowy AM, Bouvet M, Klemke RL: KRas induces a Src/PEAK1/ErbB2 kinase amplification loop that drives metastatic growth and therapy resistance in pancreatic cancer. Cancer Res 2012;72:2554-2564. Kozak G, Blanco FF, Brody JR: Novel targets in pancreatic cancer research. Semin Oncol 2015;42:177-187. Jones S, Zhang X, Parsons DW, Lin JC, Leary RJ, Angenendt P, Mankoo P, Carter H, Kamiyama H, Jimeno A, Hong SM, Fu B, Lin MT, Calhoun ES, Kamiyama M, Walter K, Nikolskaya T, Nikolsky Y, Hartigan J, Smith DR, Hidalgo M, Leach SD, Klein AP, Jaffee EM, Goggins M, Maitra A, Iacobuzio-Donahue C, Eshleman JR, Kern SE, Hruban RH, Karchin R, Papadopoulos N, Parmigiani G, Vogelstein B, Velculescu VE, Kinzler KW: Core signaling pathways in human pancreatic cancers revealed by global genomic analyses. Science 2008;321:1801-1806.

20 Waddell N, Pajic M, Patch AM, Chang DK, Kassahn KS, Bailey P, Johns AL, Miller D, Nones K, Quek K, Quinn MC, Robertson AJ, Fadlullah MZ, Bruxner TJ, Christ AN, Harliwong I, Idrisoglu S, Manning S, Nourse C, Nourbakhsh E, Wani S, Wilson PJ, Markham E, Cloonan N, Anderson MJ, Fink JL, Holmes O, Kazakoff SH, Leonard C, Newell F, Poudel B, Song S, Taylor D, Waddell N, Wood S, Xu Q, Wu J, Pinese M, Cowley MJ, Lee HC, Jones MD, Nagrial AM, Humphris J, Chantrill LA, Chin V, Steinmann AM, Mawson A, Humphrey ES, Colvin EK, Chou A, Scarlett CJ, Pinho AV, Giry-Laterriere M, Rooman I, Samra JS, Kench JG, Pettitt JA, Merrett ND, Toon C, Epari K, Nguyen NQ, Barbour A, Zeps N, Jamieson NB, Graham JS, Niclou SP, Bjerkvig R, Grutzmann R, Aust D, Hruban RH, Maitra A, Iacobuzio-Donahue CA, Wolfgang CL, Morgan RA, Lawlor RT, Corbo V, Bassi C, Falconi M, Zamboni G, Tortora G, Tempero MA; Australian Pancreatic Cancer Genome Initiative, Gill AJ, Eshleman JR, Pilarsky C, Scarpa A, Musgrove EA, Pearson JV, Biankin AV, Grimmond SM: Whole genomes redefine the mutational landscape of pancreatic cancer. Nature 2015;518:495-501. Hingorani SR, Tuveson DA: Ras redux: rethinking how and where Ras acts. Curr Opin Genet Dev 2003;13:6-13. Hruban RH, van Mansfeld AD, Offerhaus GJ, van Weering DH, Allison DC, Goodman SN, Kensler TW, Bose KK, Cameron JL, Bos JL: K-ras oncogene activation in adenocarcinoma of the human pancreas. A study of 82 carcinomas using a combination of mutant-enriched polymerase chain reaction analysis and allele-specific oligonucleotide hybridization. Am J Pathol 1993;143:545-554.

23 Collisson EA, Trejo CL, Silva JM, Gu S, Korkola JE, Heiser LM, Charles RP, Rabinovich BA, Hann B, Dankort D, Spellman PT, Phillips WA, Gray JW, McMahon M: A central role for RAF $\rightarrow$ MEK $\rightarrow$ ERK signaling in the genesis of pancreatic ductal adenocarcinoma. Cancer Discov 2012;2:685-693.

-24 Eser S, Reiff N, Messer M, Seidler B, Gottschalk K, Dobler M, Hieber M, Arbeiter A, Klein S, Kong B, Michalski CW, Schlitter AM, Esposito I, Kind AJ, Rad L, Schnieke AE, Baccarini M, Alessi DR, Rad R, Schmid RM, Schneider G, Saur D: Selective requirement of PI3K/PDK1 signaling for Kras oncogene-driven pancreatic cell plasticity and cancer. Cancer Cell 2013;23:406-420.

25 Eser S, Schnieke A, Schneider G, Saur D: Oncogenic KRAS signalling in pancreatic cancer. Br J Cancer 2014;111: 817-822.

-26 Ying H, Kimmelman AC, Lyssiotis CA, Hua S, Chu GC, Fletcher-Sananikone E, Locasale JW, Son J, Zhang H, Coloff JL, Yan H, Wang W, Chen S, Viale A, Zheng H, Paik JH, Lim C, Guimaraes AR, Martin ES, Chang J, Hezel AF, Perry SR, Hu J, Gan B, Xiao Y, Asara JM, Weissleder R, Wang YA, Chin L, Cantley LC, DePinho RA: Oncogenic Kras maintains pancreatic tumors through regulation of anabolic glucose metabolism. Cell 2012;149:656-670.

27 Yang S, Wang X, Contino G, Liesa M, Sahin E, Ying H, Bause A, Li Y, Stommel JM, Dell'antonio G, Mautner J, Tonon G, Haigis M, Shirihai OS, Doglioni C, Bardeesy N, Kimmelman AC: Pancreatic cancers require autophagy for tumor growth. Genes Dev 2011;25:717-729.

-28 Wu J, Matthaei H, Maitra A, Dal Molin M, Wood LD, Eshleman JR, Goggins M, Canto MI, Schulick RD, Edil BH, Wolfgang CL, Klein AP, Diaz LA Jr, Allen PJ, Schmidt CM, Kinzler KW, Papadopoulos N, Hruban RH, Vogelstein B: Recurrent GNAS mutations define an unexpected pathway for pancreatic cyst development. Sci Transl Med 2011;3:92ra66.

29 Landis CA, Masters SB, Spada A, Pace AM, Bourne HR, Vallar L: GTPase inhibiting mutations activate the alpha chain of Gs and stimulate adenylyl cyclase in human pituitary tumours. Nature 1989;340:692-696.

-30 Rozenblum E, Schutte M, Goggins M, Hahn SA, Panzer S, Zahurak M, Goodman SN, Sohn TA, Hruban RH, Yeo CJ, Kern SE: Tumor-suppressive pathways in pancreatic carcinoma. Cancer Res 1997;57:1731-1734. 
Chen et al.: The Emerging Genetic Basis and Its Clinical Implication in Pancreatic Cancer

$-31$

$>32$ 587.

$>52$

$>53$

$-54$

$-55$

$>56$ P, Jarvinen H, Kristo P, Pelin K, Ridanpaa M, Salovaara R, Toro T, Bodmer W, Olschwang S, Olsen AS, Stratton MR, de la Chapelle A, Aaltonen LA: A serine/threonine kinase gene defective in Peutz-Jeghers syndrome. Nature 1998;391:184-187.

57 Aretz S, Stienen D, Uhlhaas S, Loff S, Back W, Pagenstecher C, McLeod DR, Graham GE, Mangold E, Santer R, Propping P, Friedl W: High proportion of large genomic STK11 deletions in Peutz-Jeghers syndrome. Hum Mutat 2005;26:513-519.

58 Giardiello FM, Brensinger JD, Tersmette AC, Goodman SN, Petersen GM, Booker SV, Cruz-Correa M, Offerhaus JA: Very high risk of cancer in familial Peutz-Jeghers syndrome. Gastroenterology 2000;119:1447-1453.

59 Hearle N, Schumacher V, Menko FH, Olschwang S, Boardman LA, Gille JJ, Keller JJ, Westerman AM, Scott RJ, Lim W, Trimbath JD, Giardiello FM, Gruber SB, Offerhaus GJ, de Rooij FW, Wilson JH, Hansmann A, Moslein G, Royer-Pokora B, Vogel T, Phillips RK, Spigelman AD, Houlston RS: Frequency and spectrum of cancers in the Peutz-Jeghers syndrome. Clin Cancer Res 2006;12:3209-3215. 
-60 Sato N, Rosty C, Jansen M, Fukushima N, Ueki T, Yeo CJ, Cameron JL, Iacobuzio-Donahue CA, Hruban RH, Goggins M: STK11/LKB1 Peutz-Jeghers gene inactivation in intraductal papillary-mucinous neoplasms of the pancreas. Am J Pathol 2001;159:2017-2022.

61 Canto MI, Goggins M, Hruban RH, Petersen GM, Giardiello FM, Yeo C, Fishman EK, Brune K, Axilbund J, Griffin C, Ali S, Richman J, Jagannath S, Kantsevoy SV, Kalloo AN: Screening for early pancreatic neoplasia in high-risk individuals: a prospective controlled study. Clin Gastroenterol Hepatol 2006;4:766-781; quiz 665. Haluska FG, Hodi FS: Molecular genetics of familial cutaneous melanoma. J Clin Oncol 1998;16:670-682. G, Bruno W, Calista D, Albright LA, Chaudru V, Chompret A, Cuellar F, Elder DE, Ghiorzo P, Gillanders EM, Gruis NA, Hansson J, Hogg D, Holland EA, Kanetsky PA, Kefford RF, Landi MT, Lang J, Leachman SA, MacKie RM, Magnusson V, Mann GJ, Bishop JN, Palmer JM, Puig S, Puig-Butille JA, Stark M, Tsao H, Tucker MA, Whitaker L, Yakobson E; Lund Melanoma Study Group; Melanoma Genetics Consortium (GenoMEL): Features associated with germline CDKN2A mutations: a GenoMEL study of melanoma-prone families from three continents. J Med Genet 2007;44:99-106.

64 Kamb A, Shattuck-Eidens D, Eeles R, Liu Q, Gruis NA, Ding W, Hussey C, Tran T, Miki Y, Weaver-Feldhaus J, et al: Analysis of the p16 gene (CDKN2) as a candidate for the chromosome 9p melanoma susceptibility locus. Nat Genet 1994;8:23-26.

65 Lynch HT, Fusaro RM, Lynch JF, Brand R: Pancreatic cancer and the FAMMM syndrome. Fam Cancer 2008;7: 103-112.

66 Lynch HT, Brand RE, Hogg D, Deters CA, Fusaro RM, Lynch JF, Liu L, Knezetic J, Lassam NJ, Goggins M, Kern S: Phenotypic variation in eight extended CDKN2A germline mutation familial atypical multiple mole melanomapancreatic carcinoma-prone families: the familial atypical mole melanoma-pancreatic carcinoma syndrome. Cancer 2002;94:84-96.

-67 Goldstein AM, Fraser MC, Struewing JP, Hussussian CJ, Ranade K, Zametkin DP, Fontaine LS, Organic SM, Dracopoli NC, Clark WH Jr, et al: Increased risk of pancreatic cancer in melanoma-prone kindreds with p16INK4 mutations. N Engl J Med 1995;333:970-974.

-68 Rutter JL, Bromley CM, Goldstein AM, Elder DE, Holly EA, Guerry D 4th, Hartge P, Struewing JP, Hogg D, Halpern A, Sagebiel RW, Tucker MA: Heterogeneity of risk for melanoma and pancreatic and digestive malignancies: a melanoma case-control study. Cancer 2004;101:2809-2816.

69 Murphy KM, Brune KA, Griffin C, Sollenberger JE, Petersen GM, Bansal R, Hruban RH, Kern SE: Evaluation of candidate genes MAP2K4, MADH4, ACVR1B, and BRCA2 in familial pancreatic cancer: deleterious BRCA2 mutations in 17\%. Cancer Res 2002;62:3789-3793.

-70 Couch FJ, Johnson MR, Rabe KG, Brune K, de Andrade M, Goggins M, Rothenmund H, Gallinger S, Klein A, Petersen GM, Hruban RH: The prevalence of BRCA2 mutations in familial pancreatic cancer. Cancer Epidemiol Biomarkers Prev 2007;16:342-346.

-71 Hahn SA, Greenhalf B, Ellis I, Sina-Frey M, Rieder H, Korte B, Gerdes B, Kress R, Ziegler A, Raeburn JA, Campra D, Grutzmann R, Rehder H, Rothmund M, Schmiegel W, Neoptolemos JP, Bartsch DK: BRCA2 germline mutations in familial pancreatic carcinoma. J Natl Cancer Inst 2003;95:214-221.

72 Goldgar DE: Analysis of familial breast cancer in genetic analysis workshop 9: summary of findings. Genet Epidemiol 1995;12:833-836.

73 Ozcelik H, Schmocker B, Di Nicola N, Shi XH, Langer B, Moore M, Taylor BR, Narod SA, Darlington G, Andrulis IL, Gallinger S, Redston M: Germline BRCA2 6174delT mutations in Ashkenazi Jewish pancreatic cancer patients. Nat Genet 1997;16:17-18.

74 Rustgi AK: The genetics of hereditary colon cancer. Genes Dev 2007;21:2525-2538.

75 Reid MD, Saka B, Balci S, Goldblum AS, Adsay NV: Molecular genetics of pancreatic neoplasms and their morphologic correlates: an update on recent advances and potential diagnostic applications. Am J Clin Pathol 2014;141:168-180.

76 Kastrinos F, Mukherjee B, Tayob N, Wang F, Sparr J, Raymond VM, Bandipalliam P, Stoffel EM, Gruber SB, Syngal S: Risk of pancreatic cancer in families with Lynch syndrome. JAMA 2009;302:1790-1795.

-77 Alexander J, Watanabe T, Wu TT, Rashid A, Li S, Hamilton SR: Histopathological identification of colon cancer with microsatellite instability. Am J Pathol 2001;158:527-535.

78 Groden J, Thliveris A, Samowitz W, Carlson M, Gelbert L, Albertsen H, Joslyn G, Stevens J, Spirio L, Robertson $\mathrm{M}$, et al: Identification and characterization of the familial adenomatous polyposis coli gene. Cell 1991;66: 589-600.

79 Kinzler KW, Nilbert MC, Su LK, Vogelstein B, Bryan TM, Levy DB, Smith KJ, Preisinger AC, Hedge P, McKechnie D, et al: Identification of FAP locus genes from chromosome 5q21. Science 1991;253:661-665.

-80 Giardiello FM, Offerhaus GJ, Lee DH, Krush AJ, Tersmette AC, Booker SV, Kelley NC, Hamilton SR: Increased risk of thyroid and pancreatic carcinoma in familial adenomatous polyposis. Gut 1993;34:1394-1396.

-81 Solomon S, Whitcomb DC: Genetics of pancreatitis: an update for clinicians and genetic counselors. Curr Gastroenterol Rep 2012;14:112-117.

82 Whitcomb DC: Genetics of alcoholic and nonalcoholic pancreatitis. Curr Opin Gastroenterol 2012;28:501-506.

-83 Whitcomb DC, Gorry MC, Preston RA, Furey W, Sossenheimer MJ, Ulrich CD, Martin SP, Gates LK Jr, Amann ST, Toskes PP, Liddle R, McGrath K, Uomo G, Post JC, Ehrlich GD: Hereditary pancreatitis is caused by a mutation in the cationic trypsinogen gene. Nat Genet 1996;14:141-145. 
84 Witt H, Luck W, Hennies HC, Classen M, Kage A, Lass U, Landt O, Becker M: Mutations in the gene encoding the serine protease inhibitor, Kazal type 1 are associated with chronic pancreatitis. Nat Genet 2000;25:213-216.

85 Lowenfels AB, Maisonneuve P, DiMagno EP, Elitsur Y, Gates LK Jr, Perrault J, Whitcomb DC: Hereditary pancreatitis and the risk of pancreatic cancer. International Hereditary Pancreatitis Study Group. J Natl Cancer Inst 1997;89:442-446.

86 Lowenfels AB, Maisonneuve P, Whitcomb DC, Lerch MM, DiMagno EP: Cigarette smoking as a risk factor for pancreatic cancer in patients with hereditary pancreatitis. JAMA 2001;286:169-170.

87 Brand RE, Lerch MM, Rubinstein WS, Neoptolemos JP, Whitcomb DC, Hruban RH, Brentnall TA, Lynch HT, Canto MI; Participants of the Fourth International Symposium of Inherited Diseases of the Pancreas: Advances in counselling and surveillance of patients at risk for pancreatic cancer. Gut 2007;56:1460-1469.

88 Seo N, Byun JH, Kim JH, Kim HJ, Lee SS, Song KB, Kim SC, Han DJ, Hong SM, Lee MG: Validation of the 2012 international consensus guidelines using computed tomography and magnetic resonance imaging: branch duct and main duct intraductal papillary mucinous neoplasms of the pancreas. Ann Surg 2015, Epub ahead of print.

-89 Moskaluk CA, Hruban RH, Kern SE: p16 and K-ras gene mutations in the intraductal precursors of human pancreatic adenocarcinoma. Cancer Res 1997;57:2140-2143.

-90 Heinmoller E, Dietmaier W, Zirngibl H, Heinmoller P, Scaringe W, Jauch KW, Hofstadter F, RuschoffJ: Molecular analysis of microdissected tumors and preneoplastic intraductal lesions in pancreatic carcinoma. Am J Pathol 2000;157:83-92.

91 Hruban RH, Maitra A, Goggins M: Update on pancreatic intraepithelial neoplasia. Int J Clin Exp Pathol 2008;1: 306-316.

92 Wilentz RE, Geradts J, Maynard R, Offerhaus GJ, Kang M, Goggins M, Yeo CJ, Kern SE, Hruban RH: Inactivation of the p16 (INK4A) tumor-suppressor gene in pancreatic duct lesions: loss of intranuclear expression. Cancer Res 1998;58:4740-4744.

-93 Schonleben F, Qiu W, Remotti HE, Hohenberger W, Su GH: PIK3CA, KRAS, and BRAF mutations in intraductal papillary mucinous neoplasm/carcinoma (IPMN/C) of the pancreas. Langenbecks Arch Surg 2008;393:289296.

94 Bournet B, Selves J, Grand D, Danjoux M, Hanoun N, Cordelier P, Buscail L: Endoscopic ultrasound-guided fineneedle aspiration biopsy coupled with a KRAS mutation assay using allelic discrimination improves the diagnosis of pancreatic cancer. J Clin Gastroenterol 2015;49:50-56.

95 Abe T, Fukushima N, Brune K, Boehm C, Sato N, Matsubayashi H, Canto M, Petersen GM, Hruban RH, Goggins M: Genome-wide allelotypes of familial pancreatic adenocarcinomas and familial and sporadic intraductal papillary mucinous neoplasms. Clin Cancer Res 2007;13:6019-6025.

96 Wu J, Jiao Y, Dal Molin M, Maitra A, de Wilde RF, Wood LD, Eshleman JR, Goggins MG, Wolfgang CL, Canto MI, Schulick RD, Edil BH, Choti MA, Adsay V, Klimstra DS, Offerhaus GJ, Klein AP, Kopelovich L, Carter H, Karchin R, Allen PJ, Schmidt CM, Naito Y, Diaz LA Jr, Kinzler KW, Papadopoulos N, Hruban RH, Vogelstein B: Wholeexome sequencing of neoplastic cysts of the pancreas reveals recurrent mutations in components of ubiquitindependent pathways. Proc Natl Acad Sci USA 2011;108:21188-21193.

-97 Iacobuzio-Donahue CA, Wilentz RE, Argani P, Yeo CJ, Cameron JL, Kern SE, Hruban RH: Dpc4 protein in mucinous cystic neoplasms of the pancreas: frequent loss of expression in invasive carcinomas suggests a role in genetic progression. Am J Surg Pathol 2000;24:1544-1548.

-98 Moore MJ, Goldstein D, Hamm J, Figer A, Hecht JR, Gallinger S, Au HJ, Murawa P, Walde D, Wolff RA, Campos D, Lim R, Ding K, Clark G, Voskoglou-Nomikos T, Ptasynski M, Parulekar W; National Cancer Institute of Canada Clinical Trials Group: Erlotinib plus gemcitabine compared with gemcitabine alone in patients with advanced pancreatic cancer: a phase III trial of the National Cancer Institute of Canada Clinical Trials Group. J Clin Oncol 2007;25:1960-1966.

99 Gottesman MM: Mechanisms of cancer drug resistance. Annu Rev Med 2002;53:615-627.

100 Wei F, Liu Y, Bellail AC, Olson JJ, Sun SY, Lu G, Ding L, Yuan C, Wang G, Hao C: K-Ras mutation-mediated IGF-1-induced feedback ERK activation contributes to the rapalog resistance in pancreatic ductal adenocarcinomas. Cancer Lett 2012;322:58-69.

101 Shah AN, Summy JM, Zhang J, Park SI, Parikh NU, Gallick GE: Development and characterization of gemcitabineresistant pancreatic tumor cells. Ann Surg Oncol 2007;14:3629-3637.

102 Avan A, Quint K, Nicolini F, Funel N, Frampton AE, Maftouh M, Pelliccioni S, Schuurhuis GJ, Peters GJ, Giovannetti E: Enhancement of the antiproliferative activity of gemcitabine by modulation of c-Met pathway in pancreatic cancer. Curr Pharm Des 2013;19:940-950.

103 Zhang JG, Hong DF, Zhang CW, Sun XD, Wang ZF, Shi Y, Liu JW, Shen GL, Zhang YB, Cheng J, Wang CY, Zhao G: Sirtuin 1 facilitates chemoresistance of pancreatic cancer cells by regulating adaptive response to chemotherapy-induced stress. Cancer Sci 2014;105:445-454.

104 Oshima M, Okano K, Muraki S, Haba R, Maeba T, Suzuki Y, Yachida S: Immunohistochemically detected expression of 3 major genes (CDKN2A/p16, TP53, and SMAD4/DPC4) strongly predicts survival in patients with resectable pancreatic cancer. Ann Surg 2013;258:336-346.

105 Rahman M, Chan AP, Tai IT: A peptide of SPARC interferes with the interaction between caspase8 and Bcl2 to resensitize chemoresistant tumors and enhance their regression in vivo. PLoS One 2011;6:e26390.

-106 Fong PC, Boss DS, Yap TA, Tutt A, Wu P, Mergui-Roelvink M, Mortimer P, Swaisland H, Lau A, O’Connor MJ, Ashworth A, Carmichael J, Kaye SB, Schellens JH, de Bono JS: Inhibition of poly(ADP-ribose) polymerase in tumors from BRCA mutation carriers. N Engl J Med 2009;361:123-134. 